\title{
Development of a method for measuring lysine and methionine bioavailability in rumen-protected products for cattle
}

\author{
H. Rulquin ${ }^{1}$ and J. Kowalczyk ${ }^{2}$ \\ ${ }^{1}$ Unité Mixte de Recherches Production du Lait, \\ Institut National de la Recherche Agronomique \\ 35590 Saint-Gilles, France \\ ${ }^{2}$ The Kielanowski Institute of Animal Physiology and Nutrition, \\ Polish Academy of Sciences \\ 05-110 Jabłonna, Poland
}

(Received 8 May 2003; accepted 15 July 2003)

\begin{abstract}
The objective of the experiment was to find a quantitative test to determine the lysine or methionine bioavailability of rumen-protected amino acids. For these purposes we elaborated a blood test including an in vivo calibration phase and we used this test on two commercial products whose bioavailability is known (Smartamine $\mathrm{M}^{\mathrm{TM}}$ and SmartamineML ${ }^{\mathrm{TM}}$ ). Three ruminally and duodenally fistulated low-yielding $(10 \mathrm{~kg} / \mathrm{d})$ Holstein cows were used. The calibration phase consisted of relating blood plasma methionine and lysine concentrations to duodenal infusion of graded amounts of methionine and lysine. The blood plasma responses of methionine and lysine to graded amounts infused duodenally were linear. The methionine response was the same for all cows, but the lysine response varied with the cows. Quantification of the bioavailability of commercial products is achieved by relating the blood level variations, as induced by product supplementation, to those obtained by duodenal infusion during the calibration phase. Bioavailability of methionine supplied by SmartamineM ${ }^{\mathrm{TM}}$ and SmartamineML ${ }^{\mathrm{TM}}$ was 75 and $84 \%$, respectively. The reliability of the test is related to the amount of amino acid provided by the product supplementation: providing a low quantity of amino acids resulted in an overestimation of the bioavailability. This tendency is particularly clear for lysine bioavailability estimation. The proposed blood test is valuable for the determination of the bioavailability of methionine, but not lysine, of rumen-protected products.
\end{abstract}

KEY WORDS: methionine, lysine, bioavailability, blood test, dairy cattle

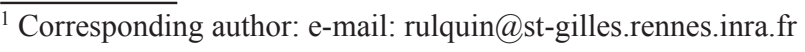




\section{INTRODUCTION}

Methionine and lysine are the most limiting amino acids of milk protein synthesis in dairy cows, as demonstrated by post-ruminal infusions of increasing doses of lysine (Rulquin et al., 1990; King et al., 1991; Schwab et al., 1992; Guinard and Rulquin, 1994) and methionine (Socha et al., 1994a,b,c; Guinard and Rulquin, 1995; Pisulewski et al., 1996). In practice, those amino acids must be given in a form that ensures their protection against degradation in the rumen and absorption in the small intestine. This is possible with raw materials like gluten meal or fish meal, for example. Bioavailability (the amount of amino acid useable by animals), however, varies greatly according to the technological treatment undergone by feedstuffs. Moreover, only small amounts of methionine or lysine can be supplemented this way. As an example, more than one kg of fish meal supplement is necessary to provide approximately $12 \mathrm{~g}$ of absorbable methionine. Therefore, a significant effort has been deployed and dedicated to the development of protected forms of pure amino acids, using different techniques.

Many tests have been developed to assess the effectiveness of this protection :

- in vitro laboratory tests (Robert, 1992)

- in sacco tests (Overton et al., 1996; Robert et al., 1997; Bach and Stern, 2000)

- in vivo tests measuring digestive flux (Robert and Williams, 1997; Koenig et al., 1999; 2002)

- tests based on variations of plasma concentrations of the protected amino acid consumed (Overton et al., 1996; Bach and Stern, 2000).

These various techniques all have advantages and disadvantages: laboratory tests in vitro are remote from in vivo reality. The methods proposed can only test $\mathrm{pH}$ sensitive forms. Tests in sacco do not take the mechanical aspects of digestion into account (mastication, rumination, transit rate in the rumen). The in sacco method cannot be used with small-sized or soluble products, the tested substrate can be contaminated by rumen bacteria, giving false or biased results, particle loss is also a risk if the grain size of the tested products is close to the mesh of the bags.

In vitro and in sacco tests are semi-quantitative tests and so give numerical but overestimated values because they do not take a number of digestive phenomena into account; they will help in segregating good products from the really bad ones as a first step, but their discriminating power is too low to precisely rate the bioavailability of the various protected amino acids. Tests that measure the duodenal digestive fluxes of free amino acids originating from protected forms are especially cumbersome and costly. They require using cannula-fitted animals and infusing flux and digestibility markers. To be quantitative, the measurement has to be performed according to equally cumbersome experimental designs (Latin square, double inversion etc.) with imprecise flux results, even in well-conducted experiments. Tests based on blood level variations have the advantage of being global and of reflecting the bioavailability of the protected product, but they are not quantitative. 
The aim of the tests described in this paper was to propose quantitative assessment methods to determine in circulating blood the additional amount of the free amino acid originated by the protected product (added amino acid bioavailability). Quantification is achieved by relating the blood level variations, as induced by product supplementation, to those obtained by duodenal infusion of known doses of pure amino acids. After verifying the linearity of blood level response according to the doses infused, that technique was applied to two commercial protected amino acid products.

\section{MATERIAL AND METHODS}

\section{Treatments}

Animal response calibration was performed by infusing water or $15 \mathrm{~g}$ DL-Met and $26 \mathrm{~g}$ L-Lys $\mathrm{HCl}$ or $20 \mathrm{~g}$ DL-Met and $38 \mathrm{~g}$ L-Lys $\mathrm{HCl}$ in the duodenum. The infusions were performed according to a $3 \times 3$ Latin square design with $4 \mathrm{~d}$ periods. At the end of the trial two calibration periods were added: $3 \mathrm{~g}$ DL-Met and $13 \mathrm{~g}$ L-Lys $\mathrm{HCl}$ and $30 \mathrm{~g}$ DL-Met and $51 \mathrm{~g}$ L-Lys HCl. Additional treatment consisted of supplementing $20 \mathrm{~g}$ DL-Met and $38 \mathrm{~g}$ L-Lys $\mathrm{HCl}$ by continuous infusion into the rumen or by introduction into the rumen cannula twice a day, $15 \mathrm{~min}$ after the distribution of feeds.

Between these two calibration periods, the bioavailability (amount absorbed/ amount supplemented) of rumen-protected amino acids was determined with several doses. The test doses were 30 and $40 \mathrm{~g}_{\text {SmartamineM }}{ }^{\mathrm{TM}}(\mathrm{SmM})$, then 88, 132 and $50 \mathrm{~g}$ SmartamineML ${ }^{\mathrm{TM}}$ (SmML), respectively. The analytical specifications of these products, protected by a $\mathrm{pH}$-sensitive coating, were as follows, \% DM: for SmartamineM ${ }^{\mathrm{TM}}$ and SmartamineML ${ }^{\mathrm{TM}}$ : 99.6 and 96.7; N: 6.53 and 9.71; Met: 78.1 and 16.8; Lys: 0 and 39.4.

The protected amino acids were introduced during 4 days in the rumen cannula twice a day, $15 \mathrm{~min}$ after the distribution of feeds. Pure amino acids were dissolved in $5 \mathrm{~kg}$ water and infused continuously with a peristaltic pump (Ismatec, Bioblock, Illkirch, France).

\section{Animals}

Three multiparous Holstein cows fitted with rumen and duodenal fistulae were used. They were fitted with a catheter inserted in the jugular vein. The cows' body weight was $776 \pm 55 \mathrm{~kg}$ and they were all in late lactation (350 \pm 8 days), producing $10 \pm 1.3 \mathrm{~kg}$ milk. 


\section{Diet and feeding}

The animals were fed a standard diet composed of (\%): maize silage, 94; tanned meal, 4.1 ( $80 \%$ soyabean and $20 \%$ rapeseed); urea, 0.7 ; mineral vitamin supplement, 1.3. That diet was fed to the amount of $14.9 \mathrm{~kg} \mathrm{DM} / \mathrm{d}$ in two equal parts at 6.30 and 18.30 , and covered $127 \%$ of energy requirements and $115 \%$ of protein requirements.

Sampling and analysis

On the last day of each experimental period, a series of blood samples $(10 \mathrm{ml})$ was collected from the jugular vein with a heparinized syringe (Monovette ${ }^{\mathrm{R}}$ Starsted) every hour from 06.00 to 17.00 . The plasma collected by centrifugation of blood at $3000 \mathrm{rpm}$ for $10 \mathrm{~min}$ at $+4^{\circ} \mathrm{C}$ was protein-depleted with sulphosalicylic acid $6 \%$ ( 1 volume of plasma to 1 volume of acid). The mixture was then centrifuged at $3000 \mathrm{rpm}$ for $10 \mathrm{~min}$. A supernatant aliquot was used to make up a sample per cow representative of the average day and the remainder was stored to study variations later in the day. The amino acid composition of those samples was determined by ion exchange chromatography with an amino acid analyser (LC 3000, Biotronik) according to Pisulewski et al. (1996).

\section{Statistical analysis}

Statistical analyses were performed according to the SAS procedure. ANOVA was used to test the difference in bioavailability of methionine from the SmM product administered in doses of 30 and $40 \mathrm{~g} /$ day and to estimate the residual standard deviation of the blood test technique.

The GLM procedure was used to compare the slopes and ordinates at the origin of calibration lines. It was also used, based on linear and quadratical orthogonal contrasts, to verify the linearity of the bioavalability results of the SmML product amino acids. The equilibrium hypothesis was tested by using dose/time interactions by the GLM repeated time procedure.

\section{RESULTS AND DISCUSSION}

\section{Control selection}

Various possible controls were tested comparatively. No significant difference was found between treatments, type of infusion (water in the duodenum vs amino acids in the rumen) or in the infusion mode (continuous or intermittent) for Met and 
Lys (Table 1). However, highly significant differences in blood Lys concentration were noted between cows. The above results showed that methionine and lysine were metabolized in the rumen, and are consistent with Patterson's results (1988).

TABLE 1

Effect of the various control treatments on methionine and lysine plasma levels, $\mathrm{mg} / 100 \mathrm{ml}$ (Trial 2)

\begin{tabular}{|c|c|c|c|c|c|c|}
\hline \multirow{2}{*}{$\begin{array}{l}\text { Control } \\
\text { Site } \\
\text { Supply }\end{array}$} & \multirow{2}{*}{$\begin{array}{c}\text { Water } \\
\text { Duodenum } \\
\text { Infusion }\end{array}$} & \multicolumn{2}{|c|}{ Met and Lys into the rumen } & \multirow{2}{*}{ SED } & \multicolumn{2}{|c|}{ P of effects } \\
\hline & & infusion & twice in $24 \mathrm{~h}$ & & cows & treatment \\
\hline Met & 0.354 & 0.348 & 0.320 & 0.044 & 0.32 & 0.67 \\
\hline Lys & 1.095 & 1.205 & 1.037 & 0.083 & 0.001 & 0.11 \\
\hline
\end{tabular}

\section{Calibration curves}

Plasma methionine or lysine levels varied linearly with the amounts of those amino acids infused in the duodenum. Indeed, the regression $\mathrm{R}^{2}$ between plasma levels and infusion amounts were between 0.90 and 0.95 for either Met or Lys. Statistically, the ordinates of origin and the slopes did not differ from one another for Met (Figure 1a) but not for Lys (Figure 1b). With Lys the ordinate of origin appeared to be related to the level of protein produced in milk. It is therefore preferable to compute the protection level of a product by using individual calibrations

(1a) Met

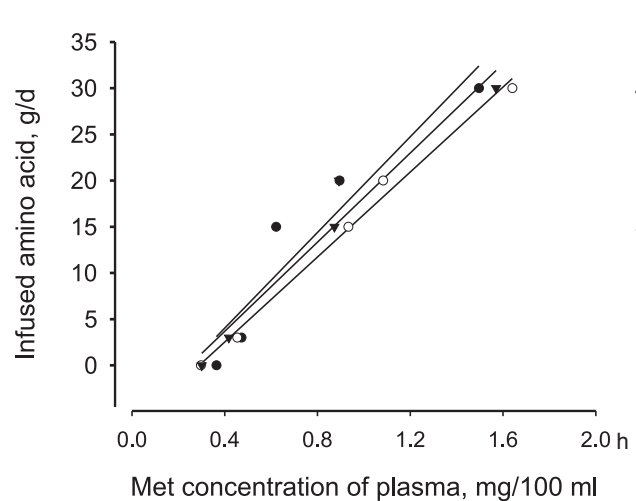

(1b) Lys

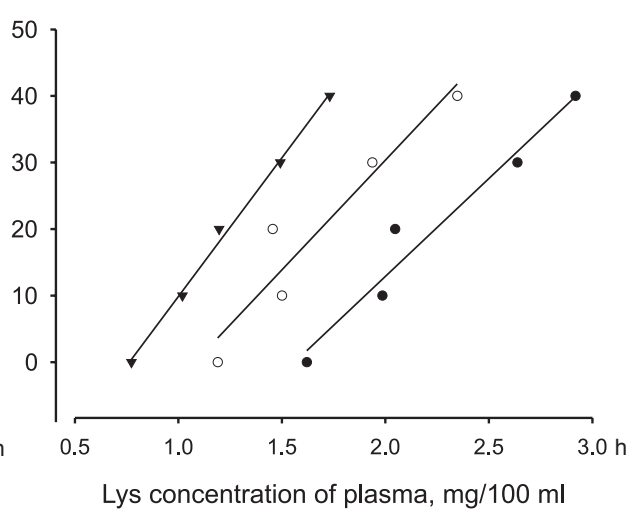

Figure 1. Individual variations of relationships between plasma of Met (1a) or Lys (1b) and amounts infused into the duodenum. Milk protein yield of cows: $\bullet$ Cow $1=189 \mathrm{~g} / \mathrm{d}$; $\circ$ Cow 2 $=249 \mathrm{~g} / \mathrm{d} ; \boldsymbol{\nabla}$ Cow $3=358 \mathrm{~g} / \mathrm{d}$ 
rather than an average calibration formula. The response being linear over a wide variation range, two calibration points for each cow are sufficient; this will reduce the method application costs.

The response linearity noted in this trial was consistent with the results obtained by Titgemeyer and Merchen (1990), King et al. (1991) and Guinard and Rulquin (1994, 1995). The infused amounts tested (3-30 g methionine and 10-40 g lysine) were similar to those applied by Guinard et al. (1994) and Guinard and Rulquin (1995) who used $32 \mathrm{~g}$ methionine and $63 \mathrm{~g}$ lysine per cow per day. Conversely, the highest dose of lysine used in this trial was much lower than that of King et al. (1991) - $180 \mathrm{~g} /$ cow per day.

In the current trial, the variation range tested was relatively wider with methionine than with lysine and the maximum methionine tested was close to the duodenal flux of dietary methionine, whereas the corresponding lysine maximum only amounted to $25 \%$ of the duodenal flux of dietary lysine. That could perhaps explain the lower accuracy of results with lysine as compared with methionine.

Blood methionine variations induced by infusion of protected products throughout the day were studied. There was a significant variation $(\mathrm{P}<0.05)$ of plasma amino acid levels along the day (Figure 2). The variability was not wider with either protected product, SmM or SmML. With SmML there was no significant interaction between blood methionine level and time. That would indicate that a

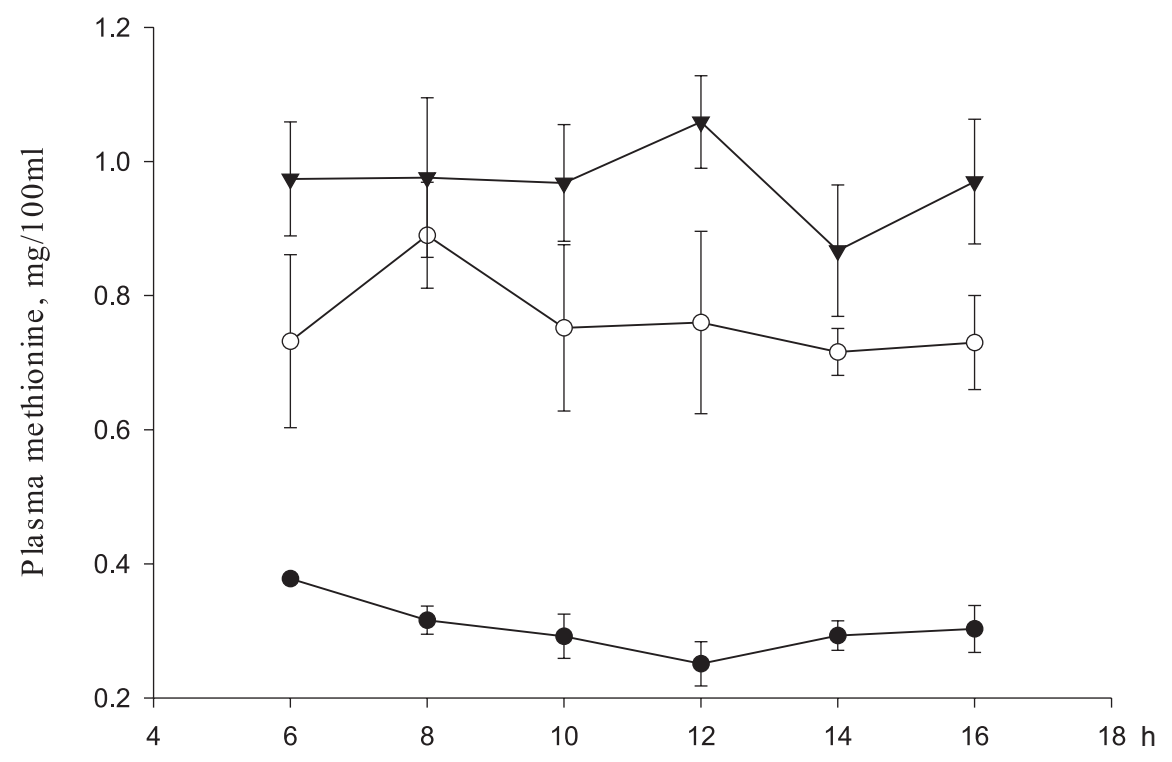

Figure 2. Diurnal variations of plasma methionine concentrations of cows supplied with graded doses of Smartamine ML ${ }^{\mathrm{TM}}:-50 \mathrm{~g}$ SmartamineML ${ }^{\mathrm{TM}},-0-88 \mathrm{~g} \mathrm{SmartamineML}^{\mathrm{TM}} \stackrel{-}{\longrightarrow} 132 \mathrm{~g}$ Smartamine $\mathrm{ML}^{\mathrm{TM}}$ 
steady state was reached after 4 days of treatment; otherwise the kinetics should have been enhanced with higher doses.

These results show, with regard to the application of the technique, that on the one hand it will be necessary to collect several blood samples on the same day, so as to obtain a half-day representative point by pooling samples, and on the other hand, that 4 days of treatment with the product under test will be sufficient to obtain a steady state.

\section{Application to commercial products}

The bioavailability level of the Smartamine ${ }^{\mathrm{TM}} \mathrm{M}$ and Smartamine ${ }^{\mathrm{TM}} \mathrm{ML}$ amino acids within the same animal were computed using the calibration curve for each cow according to the following formula:

$$
\text { amount "absorbed" = a }+ \text { b x plasma level }
$$

Bioavailability corresponded to the amount absorbed to amount supplemented ratio.

The level of methionine bioavailability was high in both products: $75 \%$ in SmM and $84 \%$ in SmML. No significant difference was found with the two doses used with SmM ( $\mathrm{P}=1$; Table 2). With SmML, methionine bioavailability tended to decrease with the dose that was used, although nonsignificantly ( $\mathrm{P}=0.11$; Table 2$)$.

This may suggest that the technique reached its limitations with very low methionine doses. Bioavailability appeared to be stable between the last two doses, which could mean that at least 15 to $20 \mathrm{~g}$ Met are required for the test to be reliable. The fact that bioavailability was the same regardless of the dose used indicates that calibration is possible with these products provided the doses are not too low (below $15 \mathrm{~g} / \mathrm{d}$ ).

The lysine bioavailability of SmML was very high: 100\% (Table 2). This result is astonishing because the coating technology is such that there is no reason for lysine bioavailability to be higher than that of methionine, especially in the same product, SmML, where it was $84 \%$ (Table 2). This was not due to any aberrant

TABLE 2

\begin{tabular}{|c|c|c|c|c|c|c|c|}
\hline \multirow{2}{*}{$\begin{array}{l}\text { Indices } \\
\text { Product, g/d }\end{array}$} & \multicolumn{2}{|c|}{ Smartamine $\mathrm{M}^{\mathrm{TM}}$} & \multirow[t]{2}{*}{ SED } & \multicolumn{3}{|c|}{ Smartamine $\mathrm{ML}^{\mathrm{TM}}$} & \multirow[t]{2}{*}{ SED } \\
\hline & 30 & 40 & & 50 & 88 & 132 & \\
\hline Met, g/d & 23.4 & 31.2 & & 8.4 & 14.8 & 22.2 & \\
\hline Lys, g/d & & & & 19.7 & 34.7 & 52 & \\
\hline \multicolumn{8}{|c|}{ Bioavailability, \% } \\
\hline Met & 75.1 & 75.1 & 3.43 & 95.3 & 79.7 & 77.7 & 10.5 \\
\hline Lys & & & & 106.3 & 84.0 & 109.3 & 18.2 \\
\hline
\end{tabular}


value because $56 \%$ of the values were above $100 \%$. As with methionine, the lysine bioavailability of SmML was unrelated to the dose used $(\mathrm{P}=0.22)$.

These high lysine bioavailability results could be related to those obtained with methionine supplemented in small doses (i.e. 95\% bioavailability with $8 \mathrm{~g}$ supplement); in that case, methionine supplementation only represented about $20 \%$ of the duodenal flux of dietary origin. Imprecision could also be greater in that case. With lysine the supplementation amounts were between 13 and $33 \%$ of the baseline duodenal flux.

This technique of protected amino acid bioavailability assessment appeared to produce good results with methionine. It could in future be simplified by using only two calibration values ( 0 and 20 or $30 \mathrm{~g}$ Met). However, it requires kinetically scheduled blood sampling in order to secure a mean value representative of one half day.

The results of the current trial revealed that methionine bioavailability did not differ between SmM (75\%) and Sm ML (84\%), and could be defined as $80 \%$. In contrast, the lysine bioavailability of SmML was too high and the reliability of the test for that determination remains to be verified. These results are concordant with those obtained by duodenal assay and faecal digestibility tests, revealing $80 \%$ mean bioavailability of methionine in SmartamineM ${ }^{\mathrm{TM}}$ (Robert and Williams, 1997). The same tests revealed, however, $87 \%$ lysine bioavailability in SmartamineML ${ }^{\mathrm{TM}}$, much lower that that obtained with the blood test technique used in the current study.

\section{CONCLUSIONS}

In contrast with in vitro, in sacco and blood tests without calibration, the blood test with calibration is quantitative. The accuracy of the technique is $3-10 \%$, whereas that of duodenal work-up would be about 20-30\% (Robert and Williams, 1997).

The results from the current trial show that the protected amino acid assessment technique produces good results, with methionine in particular. With lysine, the case needs to be confirmed. The method could be simplified by using only two calibration points ( 0 and 20 or $30 \mathrm{~g}$ methionine); it is necessary however, to define blood sampling kinetics to determine a mean value representative of the whole day. The technique is quick and requires few analysis. However, it always requires fistulated animals. In addition, calibration should be performed individually to ensure optimal precision.

The test could be simplified by using calibration with a product whose bioavailability is perfectly known; it would be necessary also that this "calibration product" be absolutely stable over long periods, which remains to be ascertained. 


\section{ACKNOWLEDGEMENTS}

The authors wish to gratefully thank Y. Lebreton for assistance with surgeries, P. Lamberton and his team for their helpful assistance, care and feeding of cows and M. Texier I. Jicquel for technical assistance.

\section{REFERENCES}

Bach A., Stern M.D., 2000. Measuring resistance to ruminal degradation and bioavailability of ruminally protected methionine. Anim. Feed Sci. Tech. 84, 23-32

Guinard J., Rulquin H., 1994. Effect of graded amounts of duodenal infusions of lysine on the mammary uptake of major milk precursors in dairy cows. J. Dairy Sci. 77, 3565-3576

Guinard J., Rulquin H., 1995. Effect of graded amounts of duodenal infusions of methionine on the mammary uptake of major milk precursors in dairy cows. J. Dairy Sci. 78, 2196-2207

King K.J., Bergen W.G., Sniffen C.J., Grant A.L., Grieve D.B., King V.L., Ames N.K., 1991. An assessment of absorbable lysine requirements in lactating cows. J. Dairy Sci. 74, 2530-2539

Koenig K.M., Rode L.M., Knight C.D., McCullough P.R., 1999. Ruminal escape, gastrointestinal absorption, and response of serum methionine to supplementation of liquid methionine hydroxy analog in dairy cows. J. Dairy Sci. 82, 355-361

Koenig K.M., Rode L.M., Knight C.D., Vázquez-Añón M., 2002. Rumen degradation and availability of various amounts of liquid methionine hydroxy analog in lactating dairy cows. J. Dairy Sci. 85, 930-938

Overton T.R., LaCount D.W., Cicela T.M., Clark J.H., 1996. Evaluation of a ruminally protected methionine product for lactating dairy cows. J. Dairy Sci. 79, 631-638

Patterson J.A., Kung L. Jr., 1988. Metabolism of DL-methionine and methionine analogs by rumen microorganisms. J. Dairy Sci. 71, 3292-3301

Pisulewski P.M., Rulquin H., Peyraud J.L., Vérité R., 1996. Lactational and systemic responses of dairy cows to postruminal infusions of increasing amounts of methionine. J. Dairy Sci. 79, 1781-1791

Robert J.C., 1992. Tests in vitro. Tests in sacco. Acides aminés protégés dans le rumen et disponible dans l'intestin. Une Technologie RPAN Originale. Tours. Journées AFTAA-CAAA, Tours (France)

Robert J.C., Mathé J., Dumont G., Morcate A., 1997. Influence of type of ration on the intestinal availability of lysine and methionine from a rumen-protected source ( $\mathrm{pH}$ sensitive coating protecting a lysine methionine core). 2-ème Carrefour des Productions Animales, Gembloux (Belgium)

Robert J.C., Williams P.E.V., 1997. Influence of forage type on the intestinal availability of methionine from a rumen-protected form. J. Dairy Sci. 80, Suppl. 1, 248 (Abstr.)

Rulquin H., Le Henaff L., Vérité R., 1990. Effects on milk protein yield of graded levels of lysine infused into the duodenum of dairy cows fed diets with two levels of protein. Reprod. Nutr. Dévelop. 30, Suppl. 2, 238s (Abstr.)

Schwab C.G., Bozak C.K., Whitehouse N.L., Olson V.M., 1992. Amino acid limitation and flow to the duodenum at four stages of lactation. 2. Extent of lysine limitation. J. Dairy Sci. 75, 3503-3518

Socha M.T., Schwab C.G., Putnam D.E., Whitehouse N.L., Kierstead N.A., Garthwaite B.D., Ducharme G.A., 1994a. Determining methionine requirements of dairy cows during peak lactation by postruminally infusing incremental amounts of methionine. J. Dairy Sci. 72 Suppl. 1, 92 (Abstr.) 
Socha M.T., Schwab C.G., Putnam D.E., Whitehouse N.L., Kierstead N.A., Garthwaite B.D., Ducharme G.A., 1994b. Determining methionine requirements of dairy cows during midlactation by postruminally infusing incremental amounts of methionine. J. Dairy Sci. 72, Suppl. 1, 93 (Abstr.)

Socha M.T., Schwab C.G., Putnam D.E., Whitehouse N.L., Kierstead N.A., Garthwaite B.D., Ducharme G.A., 1994c. Determining methionine requirements of dairy cows during early lactation by postruminally infusing incremental amounts of methionine. J.Dairy Sci. 72 Suppl. 1, 246 (Abstr.)

Titgemeyer E.C., Merchen N.R., 1990. Sulfur-containing amino acid requirement of rapidly growing steers. J. Anim. Sci. 68, 2075-2083

\section{STRESZCZENIE}

\section{Opracowanie metody pomiaru dostępności biologicznej lizyny i metioniny z preparatów chro-} nionych przed rozkładem $w$ żwaczu bydła

Celem badań było opracowanie ilościowego testu do oznaczenia dostępności biologicznej lizyny i metioniny chronionej przed rozkładem w żwaczu (Smartamine $\mathrm{M}^{\mathrm{TM}} \mathrm{i}$ Smartamine ML ${ }^{\mathrm{TM}}$ ). Doświadczenie przeprowadzono na trzech krowach holsztyńskich o niskiej produkcji mleka $(10 \mathrm{~kg} / \mathrm{d})$, z przetokami do żwacza i dwunastnicy. W fazie kalibracyjnej testu oznaczano stężenie wolnej lizyny i metioniny w krwi żyły jarzmowej i uzyskane wartości odnoszono do stopniowo zwiększanej dozy lizyny i metioniny infundowanej do dwunastnicy: stwierdzono liniową zależność pomiędzy stężeniem tych aminokwasów a ich ilością podawaną. Reakcja krów na podaną metioninę był jednakowa u wszystkich zwierząt, natomiast na lizynę różniła się między zwierzętami.

Dla ilościowej oceny dostępności biologicznej, z handlowych preparatów, aminokwasów chronionych przed rozkładem w żwaczu porównywano zmiany stężenia wolnych aminokwasów w krwi, spowodowane podaniem badanych preparatów, ze zmianami spowodowanymi podawaniem aminokwasów w fazie kalibracyjnej. Dostępność biologiczna metioniny z preparatów Smartamine $\mathrm{M}^{\mathrm{TM}}$ i Smartamine $\mathrm{ML}^{\mathrm{TM}}$ wynosiła odpowiednio 75 i 84\%. Dokładność testu zależała od ilości aminokwasów w podanym preparacie z zastrzeżeniem, że podanie małej ilości aminokwasu chronionego prowadzi do zawyżenia wartości wyników ich dostępności biologicznej. Ta tendencja była szczególnie wyraźna w przypadku oznaczania dostępności biologicznej lizyny. Opracowany test jest wartościową metodą do oznaczania dostępności biologicznej metioniny, lecz nie lizyny, z preparatów aminokwasów chronionych przed rozkładem w żwaczu. 